\title{
Women in War: Being Protected or Combatant?
}

\section{Jerry Indrawan}

Dosen Program Studi Hubungan Internasional Universitas Paramadina dan Universitas Bung Karno

Jakarta

JI Gatot Subroto Jakarta 12780

Email: jerry.indrawan@paramadina.ac.id

Diterima pada 30 Maret 2014, Disetujui pada 18 Februari 2015

\begin{abstract}
Abstrak
Dalam perang atau konflik bersenjata lainnya, secara umum wanita dikategorisasikan sebagai pihak yang rentan. Kekerasan seksual dan pelecehan terhadap perempuan sering digunakan sebagai teknik penyiksaan terhadap mereka. Penyiksaan yang bertujuan untuk menanamkan teror sebagai salah satu metode pembersihan etnis. Menganggap bahwa dalam situasi tertentu perempuan bisa dikategorisasikan sebagai kombatan, dan melihat perkambangan konflik bersenjata dalam segi internal yang membolehkan perempuan untuk ikut serta dalam situasi bermusuhan sebagai kombatan, tulisan ini ingin memberikan gambaran terhadap posisi wanita dalam perang dan konflik bersenjata dan hubungannya dengan hokum humaniter internasional.

Kata kunci: Kekerasan, Konflik Bersenjata, Kombatan, Perlindungan Perempuan, dan Hukum Humaniter Internasional.
\end{abstract}

\begin{abstract}
In war or other armed conflicts, generally women are categorized as vulnerable people. Sexual violence and harassment towards women is frequently use as a technique to committed torture against them. The torture are meant to create terror or as one of the methods of ethnic cleansing. Considering that women could be categorized as combatant in certain situation and seeing the development in internal armed conflict that allowed women to participate in hostile situation as combatant, this paper would like to give an overview towards women position in war and armed conflicts related to international humanitarian law.

Keywords: Violence, Armed Conflict, Combatant, Women Protection, and International Humanitarian Law
\end{abstract}

\section{INTRODUCTION}

For most of the 20th century the study and practice of war and international relations were dominated by men and focused on the security of states. The end of Cold War and the changing nature of violent conflict, in particular, the unique and formidable challenges posed by intrastate conflict, have changed the way in which policymakers and experts think about war and its impacts. At the conceptual level we have witnessed a shift from a perspective that sees security solely through a military lens and thus emphasized the security of states to a perspective that takes into account nonmilitary aspect of security, drawing on the notion of human security to focus on the individual and relations between individuals and groups within societies. This changed perspective has also led to greater awareness of the role of gender in international relations. At the operational level, we have witnessed a call for a more active role for the United Nation and greater sensitivity to the specific challenges faced by women in conflict situations.

The Fourth World Conference on Women, held in 
Beijing in 1995, brought the impact of war on women's lives and the issue of women's agency in international and national security issues to the attention of world leaders. Five years later, they adopted UNSCR 1325. By recognizing the importance of the role of women in preventing and resolving violent conflict, the member of Security Council handed civil society organizations and women peace activists from around the world a major victory and an authoritative instrument for further mobilization.

At the heart of the resolution are two main ideas. First, women must have the power to participate equally in all efforts to maintain and promote peace and security. The resolution recognized that women were largely absent from decision making process related to conflict prevention and resolution, and that their role must be increased. Only the full and equal participation of both men and women could provide a sustainable and lasting peace. Second, world leaders recognized that women are more exposed to physical violence than men, especially in intrastate conflicts, and that they bear inordinate burdens during conflict. Hence, special efforts need to be made to protect them from physical violence, sexual violence in particular, and to help them overcome the burdens imposed by war (Kuehnast, 2011: 1-2).

In war or other armed conflicts,generally women are categorized as vulnerable people, together with children, elderly people, sick people, and other people with disabilities. This categorization is based in a long history of violence towards women during war and other armed conflicts. Sexual violence and harassment towards women is frequently use as a technique to committed torture against them. The torture are meant to create terror or as one of the methods of ethnic cleansing. Considering that women could be categorized as combatant in certain situationand seeing the development in internal armed conflict that allowed women to participate in hostile situation as combatant, this paper would like to give an overview towards women position in war and armed conflicts related to international humanitarian law.

International Humanitarian Law (IHL) itself is a set of international rules and legal instruments that seek to minimize the destructive effects of war and prevent needless suffering. It is designed to provide legal protections on humanitarian grounds for those who are either not taking part in a conflict, such as civilians, or for the most vulnerable people who are no longer fighting, such as the wounded, the sick and prisoners(http://www.trust.org/alertnet/crisis-centre/ subtopic/international-humanitarianlaw?gclid=CJPdqbrbobUCFVAa6wodGAkAcw). Related to previous definition, this paper also would like to explain how women being perceived in terms of international humanitarian law, that sometimes keep changing. Some perceived them as combatant, some are not, depends on the situation and condition they've encountered.

\section{ANALYSIS}

\section{PROTECTION PROVISION TOWARDS WOMEN}

Protection towards women and children in emergency situation and armed conflict are stated in UN General Assembly Declaration, Resolution 3318 (XXIX) dated 14 December 1974 (http://www.undocuments.net/a29r3318.htm). Therefore, special protection for women and children as civilians are mandatory to obey by UN members, as expressed in:

1. Attacks and bombings on the civilian population, inflicting incalculable suffering, especially on women and children, who are the most vulnerable members of the population, shall be prohibited, and such acts shall be condemned.

2. The use of chemical and bacteriological weapons in the course of military operations constitutes one of the most flagrant violations of the Geneva Protocol of 1925, the Geneva Conventions of 1949 and the principles of international humanitarian law and inflicts heavy losses on civilian populations, including defenseless women and children, and shall be severely condemned.

3. All States shall abide fully by their obligations under the Geneva Protocol of 1925 and the Geneva Conventions of 1949 , as well as other instruments of international law relative to respect for human 
rights in armed conflicts, which offer important guarantees for the protection of women and children.

4. All efforts shall be made by States involved in armed conflicts, military operations in foreign territories or military operations in territories still under colonial domination to spare women and children from the ravages of war. All the necessary steps shall be taken to ensure the prohibition of measures such as persecution, torture, punitive measures, degrading treatment and violence, particularly against that part of the civilian population that consists of women and children.

5. All forms of repression and cruel and inhuman treatment of women and children, including imprisonment, torture, shooting, mass arrests, collective punishment, destruction of dwellings and forcible eviction, committed by belligerents in the course of military operations or in occupied territories shall be considered criminal.

6. Women and children belonging to the civilian population and finding themselves in circumstances of emergency and armed conflict in the struggle for peace, self-determination, national liberation and independence, or who live in occupied territories, shall not be deprived of shelter, food, medical aid or other inalienable rights, in accordance with the provisions of the Universal Declaration of Human Rights, the International Covenant on Civil and Political Rights, the International Covenant on Economic, Social and Cultural Rights, the Declaration of the Rights of the Child or other instruments of international law (http://

www2.ohchr.org/english/law/

protectionwomen.htm).

Furthermore, traditional understanding regarding to the law of war related to protection for civilian in combat situation or armed conflicts, that are widely accept and admitted, use to stated that "women and children" (but not adult men) are "innocent" and "vulnerable" (Carpenter, 2005: 296).Therefore, it is very obvious that women and children should be categorized as "civilians". Their rights must be protected at the most and also differ from the terms "combatant", which are legitimate to be killed or imposed violence conduct, for those who involve directly in hostile situation or not (Carpenter, 2005: 297).

Civilian protection against sexual violence, especially towards women has earned international recognition. It's even approved together as international crimes, and included in humanitarian international law as grave breaches, based on 1998 Rome Statute of the International Court, Geneva Conventions of 1949, jurisprudence of international criminal tribunalsof formerYugoslavia and Rwanda (United Nations, 2008: 1).

In certain armed conflict, raping is most use as a weapon for dispute parties (http://worldsavvy.org/ monitor/index.php?option=com_contentHYPERLINK "http://worldsavvy.org/monitor/index.php?option $=$ com_content\&view $=$ article $\&$ id $=589 \&$ Itemid=1036" \&HYPERLINK "http://worldsavvy.org/monitor/index.php?option $=$ com_content$\&$ view $=$ article\& id $=589 \&$ Itemid $=1036 "$ view $=$ articleHYPERLINK "http://worldsavvy.org/monitor/ index.php?option $=$ com_content $\&$ view $=$ article\&id=589\&Itemid=1036" \&HYPERLINK "http:// worldsavvy.org/monitor/index.php?option $=\mathrm{com}_{-}$content\&view $=$ article\& $\mathrm{id}=589 \&$ Itemid $=1036 " \mathrm{id}=$ = 589HYPERLINK "http://worldsavvy.org/monitor/ index.php?option $=$ com_content $\&$ view $=$ article $\&$ id=589\& Itemid=1036"\&HYPERLINK "http:// worldsavvy.org/monitor/index.php?option=com_content $\&$ view $=$ article $\& i d=589 \&$ Itemid $=$. 1036" Itemid=1036). One of the examples we can see is from the East Timor (now Timor Leste) conflict during Indonesian occupation from 1976 to 1999, where presumably there are 393 cases of raping conducted by Indonesian military or pro-integration militia (Wandita, 2008: 362-365). Therefore, protection for women caught the eye from the UN. If the goal is to destroy the social fabric of society, the rape of girls and women is seen as a particularly effective weapon. The UN recognizes four different types of 
war rape:

- Genocidal rape where specific ethnic groups are targeted.

- Opportunistic rape that occurs when the rule of law breaks down during war time.

- Political rape that is used to punish certain groups.

- Forced concubinage in which girls and women are forced into sex slavery in militias and armies.

The effects of rape are devastating on victims, families, and entire communities, as witnessed in recent conflicts in Rwanda, Bosnia, and the Democratic Republic of Congo:

- Girls and women who are raped are stigmatized, sometimes driven from their homes by the shame. Many suffer long-term physical and emotional damage, which can make them unable to fill their roles in the community.

- Many victims become pregnant, giving birth to unwanted children who are themselves stigmatized by the rape.

- Rape can be used specifically as a tool to infect women and girls with HIV when the perpetrator is HIV positive, and there are accounts of systematic rape and infection occurring with genocidal aims.

- It is also an effective tool of humiliation - of fathers, brothers, husbands, and boyfriends of victims, further fraying the norms and connections of communities.

- The threat of rape in war time is extremely disruptive to families who must forego water, food, or firewood for fear of sending their girls and women outside the home.

- In 1997 and 2001, history was made when a UN Tribunal indicted and later jailed Bosnian Serb perpetrators on charges of rape. The International Criminal Court now recognizes rape as a war crime, but experts believe the charges are under-prosecuted. Human rights activists are watching the progress of several Congolese indictees as an indicator of the international community's commitment to ending war rape.

Even the Security Council (UNSC) through
UNSCR 1820 admit that sexual violence is a matter of security that must be responded instantly. They strictly ordered an immediate and complete cessation by all parties to armed conflict of all acts of sexual violence against civilians (Kuehnast, 2011: 141-146). Then, followed with UNSCR 1888 AND UNSCR 1960 that gives mandate for peacekeeping missions to protect women and children from sexual violence during armed conflict, and requests that the Secretary General appoint a special representative on sexual violence during armed conflict (Office of the Special Representative of the Secretary-General on Sexual Violence in Conflict)". This resolutions give much attention to women agenda, peace and security, that related to sexual violence (http://www.un.org/en/ peacekeeping/issues/women/wps.shtml).

The blueprint for all the resolutions above is UNSCR 1325 as the first resolution that stresses the importance of women's equal and full participation as active agents in the prevention and resolution of conflicts, peace-building and peacekeeping (Kuehnast, 2011: 131-134). It calls on member states to ensure women's equal participation and full involvement in all efforts for the maintenance and promotion of peace and security, and urges all actors to increase the participation of women and incorporate gender perspective in all areas of peace building (http:// www.un.org/en/peacekeeping/issues/women/ wps.shtml).

Furthermore, the existence of this resolution is supported with UNSCR 1889, which strengthen women participation in peace process and the development of certain indicators use to measure the improvement of the 1325 Resolution (Kuehnast, 2011: 135140). Nevertheless, several cases prove that there are situation where women and children (http:// www.un.org/rights/concerns.htm) are not consider as vulnerable people, but they have an active role as combatant in armed conflicts, better known as insurgent (Berge, 2011: 3).Include, when women who fought are still under age, like girl soldiers. They make up almost half of the 300,000 children involved in wars, according to a report which says they are ab- 
ducted, raped and often used as currency among fighters (http://www.independent.co.uk/news/world/ africa/girl-soldiers-the-forgotten-victims-of-war509976.html).

The presence ofwomen and child soldiers is often confusing, so there are arguments to differ combatant with civilian from what they do, not because of who they are or their gender. Thus, those differences exceeding immunity norm, usually acquired based on humanitarian international law (Carpenter, 2005: 296).

Thus, if the application of women position as combatant applied, they will lose their protection as civilian, and will categorized as combatant. Therefore, the rules imposed to them aresuit to those applied in general armed conflicts, according to Den Haag convention of 1907, Geneva Conventions of 1949, and Additional Protocol I and II of 1977. The bottom line is, those provisions are intended to prevent or protect victims of armed conflicts in order to avoid from act of violence that will cause severe damage to helpless people, likepersecution, torture, rape, and murder (Adwani. 2012: 1).

In armed conflicts, treatment towards Prisoners of War (PoW) stated in Common Article 3 Geneva Conventions of 1949:

In the case of armed conflict not of an international character occurring in the territory of one of the High Contracting Parties, each Party to the conflict shall be bound to apply, as a minimum, the following provisions:

1) Persons taking no active part in the hostilities, including members of armed forces who have laid down their arms and those placed ' hors de combat ' by sickness, wounds, detention, or any other cause, shall in all circumstances be treated humanely, without any adverse distinction founded on race, color, religion or faith, sex, birth or wealth, or any other similar criteria.

To this end, the following acts are and shall remain prohibited at any time and in any place whatsoever with respect to the above-mentioned persons: a) violence to life and person, in particular murder of all kinds, mutilation, cruel treatment and torture;

b) taking of hostages;

c) outrages upon personal dignity, in particular humiliating and degrading treatment;

d) the passing of sentences and the carrying out of executions without previous judgment pronounced by a regularly constituted court, affording all the judicial guarantees which are recognized as indispensable by civilized peoples.

2) The wounded and sick shall be collected and cared for.

An impartial humanitarian body, such as the International Committee of the Red Cross, may offer its services to the Parties to the conflict.

The Parties to the conflict should further endeavour to bring into force, by means of special agreements, all or part of the other provisions of the present Convention.

The application of the preceding provisions shall not affect the legal status of the Parties to the conflict (http://www.icrc.org/ihl.nsf/WebART/375-590006).

If women engage in conflicts situation, they will be considered as PoW, so the treatment giving to them will be the same as other combatants. As describe in Article 4 Third Geneva Convention:

A. Prisoners of war, in the sense of the present Convention, are persons belonging to one of the following categories, who have fallen into the power of the enemy:

1. Members of the armed forces of a Party to the conflict as well as members of militias or volunteer corps forming part of such armed forces.

2. Members of other militias and members of other volunteer corps, including those of organized resistance movements, belonging to a Party to the conflict and operating in or outside their own territory, even if this territory is occupied, provided that such militias or volunteer corps, including such organized resistance movements, 
fulfill the following conditions:

a) That of being commanded by a person responsible for his subordinates;

b) That of having a fixed distinctive sign recognizable at a distance;

c) That of carrying arms openly;

d) That of conducting their operations in accordance with the laws and customs of war.

3. Members of regular armed forces who profess allegiance to a government or an authority not recognized by the Detaining Power.

4. Persons who accompany the armed forces without actually being members thereof, such as civilian members of military aircraft crews, war correspondents, supply contractors, members of labour units or of services responsible for the welfare of the armed forces, provided that they have received authorization from the armed forces which they accompany, who shall provide them for that purpose with an identity card similar to the annexed model.

5. Members of crews, including masters, pilots and apprentices, of the merchant marine and the crews of civil aircraft of the Parties to the conflict, who do not benefit by more favourable treatment under any other provisions of international law.

6. Inhabitants of a non-occupied territory, who on the approach of the enemy spontaneously take up arms to resist the invading forces, without having had time to form themselves into regular armed units, provided they carry arms openly and respect the laws and customs of war.

B. The following shall likewise be treated as prisoners of war under the present Convention:

1. Persons belonging, or having belonged, to the armed forces of the occupied country, if the occupying Power considers it necessary by reason of such allegiance to intern them, even though it has originally liberated them while hostilities were going on outside the territory it occupies, in particular where such persons have made an unsuccessful attempt to rejoin the armed forces to which they belong and which are engaged in combat, or where they fail to comply with a summons made to them with a view to internment.

2. The persons belonging to one of the categories enumerated in the present Article, who have been received by neutral or non-belligerent Powers on their territory and whom these Powers are required to intern under international law, without prejudice to any more favourable treatment which these Powers may choose to give and with the exception of Articles 8, 10, 15, 30, fifth paragraph, 58-67, 92, 126 and, where diplomatic relations exist between the Parties to the conflict and the neutral or non-belligerent Power concerned, those Articles concerning the Protecting Power. Where such diplomatic relations exist, the Parties to a conflict on whom these persons depend shall be allowed to perform towards them the functions of a Protecting Power as provided in the present Convention, without prejudice to the functions which these Parties normally exercise in conformity with diplomatic and consular usage and treaties.

C. This Article shall in no way affect the status of medical personnel and chaplains as provided for in Article 33 of the present Convention (http:// usmilitary.about.com/library/milinfo/genevacon/ blart-4.htm).

\section{WOMEN AS COMBATANT}

Women as combatant has exist a long time ago, whether by tradition, enforced due certain situation and condition, also voluntarily. Some countries are known to have a good women combatant (Lindsey, 2001: 23-25). In Africa, there are more than 25\% of female soldiers in Eritrea armed forces, and then The Revolutionary Nuns act as Muammar Gaddafi private guard in Libya, and gender freedom in Gambia mili- 
tary. In Asia, women combatant has a decent place in Korea, China, Sri Lanka, Nepal, even Israel. In Nepal, women combatant are estimated to reach around $40 \%$ of People's Liberation Army, who fought against the government.

The existence of women combatant are also spotted in several Eastern European countries, Canada, and even United States, although their involvement in military operation is being challenge due to some cases regarding violent treatment against them did by their men compatriots (http://www.time.com/time/ magazine/article/0,9171,1968110,00.html). Meanwhile, women recruitment as combatant in Latin America was also motivated by a number of things, which are:

First, it was a pragmatic strategy employed by the guerrillas in order to receive the increased popular that was needed in the warfare of modern guerrillas, and secondly it was a development influenced by the increasing feminist awareness in the world, which sensitize guerrilla leaders to women's rights issues and made them incorporate gender in their socialist ideology (Berge, 2011: 8).

In Protection of civilians (PoC) document, we can see frequency of rhetorical references incorporating sex according to context.

Reading table attached, reference that mention women as combatant and men also, turns out wasn't too much different after all. Although, it was admitted that women still considered as vulnerable people, victim, and main target of violence act.

Interesting findings in ICRC's Women and War research, also mention about the existence of women as combatant, remembering various events experienced by women during war (Carpenter, 2005: 324). Aside from being active as combatant, women also serves to give protection for other civilians. Regarding to this, The UNSCR 1325, try to call for women involvement in peacekeeping efforts. This is useful especially considering the comparative advantage they have when face war crime cases or act of violence towards women in armed conflicts. Lastly, UNSC also address Policy Directive for Gender Equality in United Nations
Department of Peacekeeping Operations (UNDPKO, 2006). Eventhough, the number of women involve in UN Peacekeeping Operations are still low, but there is an increasing trend, in line with the accretion of more than double since this policy was first enacted in 2005 (http://www.un.org/en/peacekeeping/documents/ gender_scres1325_chart.pdf).

\section{Tabel 1.}

Frequency of Rhetorical References Incorporating Sex According to Context, PoC Documents 19992003 (Carpenter, 2005: 302).

$\begin{array}{ll}\text { Context of Sex Reference } & \text { Frequency } \\ \text { "Women and children" } & 163 \\ \text { "Women and children" to signify "civilian" } & 44 \\ \text { "Especially" or "including women and children" } & 60 \\ \text { "Women" as "vulnerable" } & 56 \\ \text { "Women" as "parents" or "peacemakers" } & 29 \\ \text { Special protection needs of "W/C" } & 33 \\ \text { "Women and children" as victims } & 79 \\ \text { "Women and children" as deliberate targets } & 42 \\ \text { "Women and children" as primary } & 27 \\ \text { victims/targets } & \\ \text { "Women" as combatants } & 6 \\ \text { "Men" as victims/targets } & 6 \\ \text { "Men, women and children" } & 9 \\ \text { "Men" specifically mentioned as civilians } & 3 \\ \text { "Men" as "vulnerable" } & 1 \\ \text { "Men" as parents } & 1 \\ \text { "Men" as perpetrators/combatants } & 7\end{array}$

\section{THE EXISTENCE OF WOMEN COMBATANT FACTION}

The existence of women role as combatant is also widely seen in terrorist groups. Although, we have seen many examples in the past regarding to women suicide bomber, however there are escalation in jihad warrior combat unit who is fully consist of women in al-Qaeda group. Women combat unit known as Burkha Brigade, has an increasing role in attack towards the Coalition Army in Afghanistan (http:// frontpagemag.com/2012/frank-crimi/al-qaedas-femalesuicide-bomber-death-cult//). Other examples are in Afghanistan and Pakistan. The presence of women guerillas in Liberation Tigers of Tamil Eelam in Sri 
Lanka triggered debates whether is a sign of gender equality or only as a form of coercion suffered by women (Alison, 2003: 37-54). Same thing in Pakistan, women guerillas, sometimes under age, are trained by Taliban to be suicide bomber.

In Moeslim countries like Afghanistan and Pakistan, the presence of such women combatant are more because of coercion, abduction, or human trafficking, including under age recruitment, and widows who no longer have income and livelihood after their husband and children died in war (Lindsey, 2001: 31 \& Crimi, 2012).Therefore, existing motive are not always about vengeance or to continue an holy war let say, but merely based on desperation in effort to survive living without men (muhrim) as breadwinner (http:// www.time.com/time/world/article/ 0,8599,1817158,00.html).

During the Iraq war, al-Qaeda in Iraq ordered the rape of women as a way to fill its suicide bomber ranks. Since a raped woman is viewed in many Muslim societies as having brought shame to her family, the terrorists would then coerce the defiled woman into believing her familial dishonor could be erased by her martyrdom (http://frontpagemag.com/2012/frankcrimi/al-qaedas-female-suicide-bomber-death-cult/). Another from Afghanistan, Afghan special police now train women who are part of a unit to conduct searches when insurgents are suspected of using the women and children in the village to hide items such as weapons, drugs and other devices such as cell phones and documents. In Afghan culture, men do not enter a woman's room or search a female, even during an official action. Insurgents took advantage of forces who respected the customs and culture of Afghans by simply handing their weapons to the women and children of the household or even dressing themselves in burkas to avoid being searched or discovered by members of the security forces (http:// www.dvidshub.net/news/80546/female-engagementteams-foil-insurgent-tactics).

In other parts of the world, several motives behind the existence of women mobilization in Latin America can be seen in this following list (Berge, 2011: 22):

\begin{tabular}{|c|c|}
\hline "Greed" & $\begin{array}{l}\text { Receiving a salary/economical } \\
\text { benefits }\end{array}$ \\
\hline \multirow[t]{2}{*}{ "Grievance" } & Ideological reasons \\
\hline & Revenge \\
\hline Social networks & $\begin{array}{l}\text { Friends/relatives in the } \\
\text { guerrilla }\end{array}$ \\
\hline Survival & $\begin{array}{l}\text { Escaping poverty } \\
\text { Escaping threats }\end{array}$ \\
\hline $\begin{array}{l}\text { Proximity dominated } \\
\text { territory }\end{array}$ & Growing up in guerrilla \\
\hline \multirow[t]{2}{*}{$\begin{array}{l}\text { Gender related } \\
\text { reasons }\end{array}$} & Escaping domestic violence \\
\hline & $\begin{array}{l}\text { Desire to transgress gender } \\
\text { norms }\end{array}$ \\
\hline Other & $\begin{array}{l}\text { Forced recruitment } \\
\text { Wanting fun/adventure }\end{array}$ \\
\hline
\end{tabular}

On one side, the presence of women combatant can contribute to achieve the purpose of their cause, however it is unfortunate that women combatant sometimes use as an excuses from opposing side, eventhough there are no evidence of their existence in particular areas. However, more sad thing happen if women combatant are being poorly treated by their men compatriots. Some cases related to this also happens to Free Aceh Movement (GAM) women soldier in Aceh, traditionally called Inong Balee, although in the beginning the name was referring to widow soldiers who try to continue their husband struggle

(http://www.thejakartapost.com/news/2003/06/ 02/child-and-female-soldiers-reality-aceh-war.html).

The presence of disguised women combatant has been widely recognized, beside as suicide bomber that mostly done in conflict areas, like Afghanistan, Iraq, and Palestine, they often use as spy. Many misplaced attacks on women in Aceh was also happened because they considered as "cuak" or enemy in the blanket, or enemy spy. This condition bring severe trauma to women in conflict areas, especially in Aceh (http:// www.atjehcyber.net/2011/11/bukan-cuak-bukaninong-balee.html). 


\section{CIVILIAN PROTECTION NETWORK}

Transition happens in transnational community or global society is what recognized as civilian protection network (Carpenter, 2005: 298). This network covers non-government bureaucrat, civilian, journalist, and statesman which assumes that war affected civilian protection norms must be respected, and lead to the implementation of such norms spreading through the action of persuasion and have clear purpose.

The Protection of Civilians (PoC) should be an integral part in human rights regime that supposed to be respected together for the sake of human security all over the world, that are now related to one another (Carpenter, 2005: 299). This protection should also cover the protection for combatant who has lost the war, hors de combat (Out of action due to injury or damage), or other causes which led to the ex-combatant transition into civilian. Sometimes, miss treatment towards ex-combatant proved to be crucial, due to the possibility of conflict re-emerging, like it happens in Sri Lanka when former members of Liberation Tigers of Tamil Eelam which have no place in the government or the army (http://www.insightonconflict.org/ 2013/01/reconciliation-post-war-sri-lanka/).

Thisproblem also occurs in several African countries, such as Sierra Leone, Rwanda, and Liberia, where many of ex-women combatants are unable to involve themselves in post-conflict activities. One example, the Disarmament, Demobilization, and Reintegration (DDR) program was not applied well because they have difficulties to re-integrate, socially, politically, or economically (Nilsson. 2011: 39). Nevertheless, we should separate them from the use of arms in order to assist them to be welcomed in their society and family once again.

\section{CONCLUSION}

Generally women are still consider as vulnerable people and need to be protected. However, the existence of women as combatant is undeniable, and the trend is predictable rising due to the growing numbers of conflicts in the world today. What we need to do is to make sure that the implementation of international humanitarian law, and human rights principles works properly. This is urgent because without proper law and regulation that protection their rights, combatant or non-combatant, women will always become victim of conflictual situation

Regarding to that, there are stillmany woman forced as combatant all around the world nowadays. So, civilian protection networks should give input to regarding to the whereabouts. Beside that, the community should take its role to prevent conflict reescalation and to try to give ex-women combatant to earn their place in the society, and perhaps being involved in post conflict programs. In addition, if they can participate in such programs, they can contribute themselves in peace-building efforts and other means to empower themselves.

\section{BIBLIOGRAPHY}

About US Military. No date. Geneva Convention relative to the Treatment of Prisoners of War Article 4 on 1949 Third Geneva Convention. (Online),

http://usmilitary.about.com/library/milinfo/genevacon/blart-4.htm, access date 23 January 2013.

Adwani. 2012. Perlindungan terhadap Orang-orang dalam Daerah Konflik Bersenjata Menurut Hukum Humaniter Internasional. Jurnal Dinamika Hukum, Vol. 12, No. 1 January 2012.

Alison, Miranda. 2003. Cogs in the Wheel? Women in the Liberation Tigers of Tamil Eelam. The Civil War, 6(1).

Ard, Michael. 2011. Female Engangement Teams Foil Insurgent Tactics. (Online), http://www.dvidshub.net/news/80546/femaleengagement-teams-foil-insurgent-tactics, access date 23 January 2013.

Background Document: Session II Parliamentary Hearing at the United Nations. 20-21 November 2008. Sexual Violence against Women and Children in Armed Conflict. New York: United Nations Development Program.

Berge, Agnes. 2011. War as a 'Window of Opportunity? Gender Aspects of the Mobilization and Recruitment to Columbian FARCEP. Thesis. Uppsala: Department of Government Uppsala University.

Carpenter, Charli. 2005. Women, Children and Other Vulnerable Groups: Gender, Strategic Frames and the Protection of Civilians as Transnational Issue. International Studies Quarterly, 45.

Crimi, Frank. 2012. Al-Qaeda's Female Suicide Bomber Death Cult. (Online), http://frontpagemag.com/2012/frank-crimi/al-qaedasfemale-suicide-bomber-death-cult/, access date 25 January 2013.

El-Asyi. 2011. Bukan Cuak, Bukan Inong Balee. (Online), http:// www.atjehcyber.net/2011/11/bukan-cuak-bukan-inong-balee.html, access date 26 January 2013

Ghosh, Bobby. 2008. The Mind of a Female Suicide Bomber. (Online), http://www.time.com/time/world/article/0,8599,1817158,00.html, access date 24 January 2013. 
Gibbs, Nancy. 2010. Sexual Assaults on Female Soldiers: Don't Ask, Don't Tell. (Online), http://www.time.com/time/magazine/article/ 0,9171,1968110,00.html, access date 24 January 2013.

Global Status of Women. 9 May 2009. Women as Victims of War. (Online), http://worldsavvy.org/monitor/index.php?option=com_contentHYPERLINK "http://worldsavvy.org/monitor/ index.php?option=com_content\&view $=$ article\&id $=589 \& \mathrm{ltemid}=-$ 1036"\&HYPERLINK "http://worldsavvy.org/monitor/index.php?option=com_content\&view $=$ article\&id $=589 \&$ ltemid $=$ 1036"view=articleHYPERLINK "http://worldsavvy.org/monitor/ index.php?option $=$ com_content\&view $=$ article\&id $=589 \&$ Itemid=1036"\&HYPERLINK "http://worldsavvy.org/monitor/ index.php?option $=$ com_content $\&$ view $=$ article\&id $=589 \&$ ltemid$=1036$ "id =589HYPERLINK"http://worldsavvy.org/monitor/ index.php?option $=$ com_content\&view $=$ article\&id $=589 \&$ Itemid=1036"\&HYPERLINK "http://worldsavvy.org/monitor/ index.php?option $=$ com_content\&view $=$ article\&id $=$ 589\&|temid =1036" Itemid =1036, access date 2 February 2013.

ICRC. No date. Convention (III) relative to the Treatment of Prisoners of War. Geneva, 12 August 1949. Part I: General Provisions, Article 3. (Online), http://www.icrc.org/ihl.nsf/WebART/375590006, access date 24 January 2013.

Kuehnast, Kathleen, et all. 2011. Women and War: Power and Protection in the 21st Century. Washington D.C: United States Institute of Peace Press.

Lindsey, Charlotte. 2001. Women Facing War. Switzerland: ICRC.

Nilsson, Johanna. 2011. The Forgotten Soldier: Reintegration of Female Soldiers and the Implementation of UNSCR 1325 - A comparative case study of Sierra Leone and Liberia. Thesis. Uppsala: Department of Goverment Uppsala University.

OHCHR. 2013. Declaration on the Protection of Women and Children in Emergency and Armed Conflict.

(Online), http://www2.ohchr.org/english/law/protectionwomen.htm, access date 26 January 2013.

Sengupta, Kim. 2005. Girl Soldiers: The Forgotten Victims of War. (Online), http://www.independent.co.uk/news/world/africa/girlsoldiers-the-forgotten-victims-of-war-509976.html, access date 08 February 2013.

The Jakarta Post. 2 June 2003. Child and Female Soldiers a Reality in Aceh War. (Online), http://www.thejakartapost.com/news/2003/06/ 02/child-and-female-soldiers-reality-aceh-war.html, access date, 24 January 2013.

Thomson Reuters Foundation. 2013. International Humanitarian Law. (Online), http://www.trust.org/alertnet/crisis-centre/subtopic/ international-humanitarianlaw?gclid=CJPdqbrbobUCFVAa6wodGAkAcw, access date 30 January 2013.

UN. No date. Child Soldiers. (Online), http://www.un.org/rights/ concerns.htm, access date 08 February 2013.

UN Documents. 16 December 1974. Declaration on the Protection of Women and Children in Emergency and Armed Conflict.(Online), http://www.un-documents.net/a29r3318.htm, access date 5 February 2013.

UNDPKO. No date. DPKO/OMA Statistic Report on Female Military and Police Personnel in UN Peacekeeping Operations. (Online), http://www.un.org/en/peacekeeping/documents/ gender_scres1325_chart.pdf, access date 24 January 2013. UNDPKO. 2006. DPKO Policy Directive: Gender Equality in UN Peacekeeping Operations. New York: UNDPKO.

UN Peacekeeping. No date. Women, Peace, and Security.

(Online), http://www.un.org/en/peacekeeping/issues/women/wps.shtml, access date 26 January 2013.

Walton, Oliver. 10 January 2013. Reconcilliation in Post-War Sri Lanka. (Online),

http://www.insightonconflict.org/2013/01/reconciliation-post-war-srilanka/, access date 30 January 2013.

Wandita, Galuh, et all. 2008. Belajar Mengupayakan Reparasi di TimorLeste: Menjangkau Para Korban Perempuan. In Ruth Rubio-Marin (ed), Perempuan Menggugat: Masalah Gender dan Reparasi dalam Kejahatan Hak Asasi Manusia. Jakarta: Elsam. 